Etnográfica

Revista do Centro em Rede de Investigação em

Antropologia

vol. $15(2) \mid 2011$

Vol. $15(2)$

\title{
David J. Webster, A Sociedade Chope: Indivíduo e Aliança no Sul de Moçambique (1969-1976)
}

\section{Deborah James}

\section{(2) OpenEdition \\ Journals}

Electronic version

URL: https://journals.openedition.org/etnografica/1002

DOI: 10.4000/etnografica.1002

ISSN: 2182-2891

\section{Publisher}

Centro em Rede de Investigação em Antropologia

\section{Printed version}

Date of publication: 1 June 2011

Number of pages: 403-404

ISSN: 0873-6561

\section{Electronic reference}

Deborah James, "David J. Webster, A Sociedade Chope: Indívíduo e Aliança no Sul de Moçambique (1969-1976)", Etnográfica [Online], vol. 15 (2) | 2011, Online since 23 October 2011, connection on 12 February 2022. URL: http://journals.openedition.org/etnografica/1002 ; DOI: https://doi.org/10.4000/ etnografica.1002

Etnográfica is licensed under a Creative Commons Attribution-NonCommercial 4.0 International License. 
David J. Webster

A SOCIEDADE CHOPE: INDÍVÍDUO E ALIANÇA NO SUL DE MOÇAMBIQUE (1969-1976)

Lisbon, Imprensa de Ciências Sociais, 2009, 457 pp.

I was an undergraduate student of David Webster's. He shared many stories about his fieldwork but never published the thesis which has eventually, about 30 years later, been translated into Portuguese. His students, including me and João de Pina Cabral, who initiated and edited this Portuguese edition, knew him as preoccupied with Marxist theory and with matters such as proletarianisation, cheap labour power and exploitation. He seemed dismissive of his earlier work with the Chopi, on the grounds that it was concerned with ideas - about factions, brokers, individual transactions and the like - which he had begun to regard as trivial since they had no bearing on the fundamental inequalities of southern African society. His new preoccupations dovetailed with and fed into his anti-apartheid activism and, tragically, to his assassination in 1982 at the hands of state agents.

Does the book reveal insights of which Webster, had he survived, might now have revised his opinion? At first one does indeed get the sense that the book is framed by theoretical perspectives from earlier decades Bailey, Turner, and Barth are particularly in evidence - and that even these writers, who help him explain the flexibility and transactive character of Chopi society, cannot rescue him from a sort of residual morphological structuralism which seems difficult to reconcile with such flexible negotiability. But reading further, what distinguishes Webster's account and gives it enduring interest in the present is its revelation that individualism and flexible leadership arrangements are not counterposed against more structured group membership and chieftainship, but rather are intricately interwoven with, even productive of, such structures.

Webster's book reveals that this was a society, compared to others in the region, that favoured individuality to an unusual extent. Yet this was individuality of a special type. Chopi norms dictate a deep commitment to kinship values and to the solidarity of local groups. But Webster's detailed examination of who did what with whom (who lived together in a "vicinage" or neighbourhood, who called whom to participate in work parties, who attended ancestral rituals, and especially who supported bids for leadership), reveals that the groups which formed for these purposes comprised people from far-flung regions recruited by a leader on the basis of personal allegiance. In a manner reminiscent of Barth's writing, dislike for and enmity towards a rival leader was also a factor in producing solidarity. The ability to build up widespread networks and strong fields of allegiance were the only real basis on which successful leadership bids could be based; their success was, in turn, the necessary basis for individualism and autonomy.

In short, Webster found something almost systemic about this tendency to individualism. Chopi are in the habit of sending their children out to be fostered, and of naming children after people to whom they may not be related, but with whom the children may then end up residing. These two features, together with an injunction to marry far away (inevitably leading to swift divorce), provides a structural basis for the formation of allegiances which are easily formed but easily broken. Their severing then provides a blueprint for factional splits at moments when leadership bids are made. This, then, is an individualism rather different to that documented by recent anthropologists with 
an interest in social breakdown, inequality, and the competitiveness of capitalism, etc. It is an individualism deeply rooted in the fabric of sociality itself.

One key historical point, made in the introduction but not returned to, might have helped Webster to explain the features of this society. The Chopi do not constitute a centralized polity, nor do they have a long history in the area. The people known by this name have come into being as a collectivity largely as a result of political disturbances in the region: in particular the conquest by the warrior chief Soshangane and the rule by his successors over the Gaza empire. These events in turn resulted from wider violent conflicts and conquests further south - originating in the expansion of the Zulu kingdom under Shaka - which became known as the mfecane or difaqane. In essence, the Chopi are a loose group of refugees and remnants which formed on the margins of big conquests and population movements. The result, more than a century later, was a people continuing to make their lives in an improvisatory, almost anarchic manner. Chiefs, for example, were unable to control their subjects by withholding land, since dissident subjects were in a position simply to look for a willing sponsor who offered the prospects of settling elsewhere. As Webster puts it, "immigration is the Chopi way of life": their readiness to travel to the Witwatersrand to work on the mines may well have been facilitated by, but also facilitated, this tendency to make and break formations, and to move from one place and set allegiances to another. While residing in mine compounds, their extraordinary musical and dance tradition and their large xylophone (timbila) orchestras became known to the rest of the world. But perhaps more importantly for the Chopi, this music plays a key part in the drama of Chopi fission and fusion. Webster shows how lyrics are often used to excoriate rivals in leadership contests on the one hand, but to celebrate the overall unity of groups once such contests have been won on the other.

From one point of view, then, the Chopi of the 1960s appear as a quintessential society "in dissolution" as a result of widespread disturbances in an earlier period. Such dissolution fits logically with, and possibly caused, their loosely-structured and individualistic style of politics, law, work, and the like. Yet something would have been lost had Webster not described in detail, as he does here, the group dynamics underpinning this individualism. Some of us and some of our students have perhaps allowed ourselves to become lazy about exploring the "structures" upon which "events" depend for their significance (Sahlins, Islands of History): this intriguing book reminds us that we ought to give our attention to such things once again.

\author{
Deborah James \\ Department of Anthropology, \\ London School of Economics \\ and Political Science, UK
}

